\title{
DAMPAK PERIKANAN TANGKAP TERHADAP SUMBERDAYA IKAN DAN HABITATNYA DI PERAIRAN PANTAI TABUKAN TENGAH KEPULAUAN SANGIHE
}

\author{
(The Impact of Fishing Fisheries on the Fish Resources and \\ Their Habitats in Tabukan Tengah Waters, Kepulauan Sangihe)
}

\author{
Joneidi Tamarol ${ }^{1}$, Alfret Luasunaung ${ }^{2}$, Johnny Budiman ${ }^{2}$ \\ ${ }^{1}$ Politeknik Negeri Nusa Utara Tahuna Sulawesi Utara \\ ${ }^{2}$ Fakultas Perikanan dan Ilmu Kelautan Universitas Sam Ratulangi, Manado, Sulawesi Utara
}

\begin{abstract}
Overfishing and environmental degradation from fishing activities result in changes in aquartic ecosystems, and almost all fishing gears could cause habitat damages. This study attempted to eyaluate the impact of different fishing gears utilized by traditional fishermen on the fish resources and their habitats and formulate an environmenttal friendly fishing fisheries concept. Data collection used two approaches, through a long-term catch analysis and a direct field observation on the fishing process. Results found that several fishing gears used were potential to cause damages on botton habitats due to the operational technique and the treatment to the gear itself. Beside that, some gears were also potential to unbalance the stability and the the sustainability of the fish resources due to the utilization of excessively small-sized mesh. Based on the internal factor analysis strategy (EAS) and the external factor analysis strategy (EFAS), the use of fish traps, circling gill nets, and turtle targeting hand lines in the coral reef area were potential to cause direct negative impact on the coral reefs and the sustainability of the fish resources.
\end{abstract}

Keywords: impact, habitat damage, resources damage, over fishing, selectivity.

Kelebihan tangkap dan degradasi lingkungan datjkegiatan perikanan mengakibatkan perubahan ekosistem perairan dan hampir semua alat tangkap ikan đapat menyebabkan kerusakan habitat. Penelitian ini bertujuan mengevaluasi dampak alat tangkap yang digunakan oleh nelayan di perairan pantai Tabukan Tengah, Kabupaten Kepulauan Sangihe terhadap Jsumberdaya dan lingkungan dan merumuskan konsep kebijakan pengembangan perikanan tangkap yang ramah lingkungan. Pengumpulan data dilakukan menggunakan dua pendekatan yakni menganalisis hasil tangkapan untuk jangka waktu yang panjang dan pengamatan langsung terhadap proses penangkapan ikan. Hasil menunjukkan bahwa beberapa alat tangkap yang digunakan berpotensi megusak habitat dasar perairan karena tehnik pengoperasiannya dan perlakuan terhadap alat tangkap tersebut. Di samping itu, beberapa jenis alat tangkap berpotensi merobah stabilitas dan keberlangsungan sumberdaya ikan karena penggunaan mata jaring berukuran sangat kecil. Berdasarkan strategi analisis faktor internal dan strategi analisis faktor eksternal, maka penggunaan bubu ikan, jaring insang lingkar, jala lempar dan ladung penyu di daerah terumbu karang memiliki dampak negatif bagi terumbu karang dan keberlanjutan sumberdaya ikan.

Kata kunci: dampak, kerusakan habitat, kerusakan sumberdaya, tangkap lebih, selektivitas.

\section{PENDAHULUAN}

Sumberdaya ikan bersifat akses terbuka, sehingga siapa saja baik nelayan dari kawasan tersébut maupun dari luar kawasan, dapat memanfaatkannya. Aktivitas penangkapan ikan dengan cepat akan terkonsentrasi pada daerahdaerah potensial yang terbatas. Hal ini sebenarnya akan menurunkan produktivitas atau pendapatan setiap individu pelakunya sehingga akibatnya akan terjadi kerusakan lingkungan karena terpaksa harus menggunakan segala cara (Reppie et al, 2010). Di satu pihak sumberdaya hayati laut cenderung tidak ekonomis lagi jika dieksploitasi, untuk terus-menerus memenuhi kebutuhan umat manusia yang jumlahnya terus meningkat dengan pesat; sedangkan di lain pihak, ketersediaan sumberdaya alam terus menurun akibat degradasi ekosistem laut tak terkendali (Reppie dan Budiman, 2007).

Perairan pesisir Pulau Sangihe, Kabupaten Kepulauan Sangihe memiliki hamparan terumbu karang yang cukup luas, tetapi sedang mengalami penurunan kualitas yang serius akibat aktivitas manusia. Kegiatan perikanan tradisional di wilayah pesisir tersebut sering dianggap salah satu faktor utama yang mengakibat- 
kan perubahan ekosistem perairan, diantaranya perairan pantai Tabukan Tengah.

Menjawab permasalahan tersebut maka dipandang perlu suatu kajian tentang dampak pengoperasian beberapa jenis alat tangkap yang digunakan oleh nelayan lokal terhadap kerusakan lingkungan dan sumberdaya di Perairan Sangihe terutama di Tabukan Tengah. Tujuan penelitian yang hendak dicapai adalah untuk mengevaluasi adanya dampak alat tangkap yang digunakan oleh nelayan di perairan tersebut terhadap sumberdaya dan lingkungan dan merumuskan konsep kebijakan pengembangan perikanan tangkap yang ramah lingkungan.

\section{METODE PENELITIAN}

Lokasi penelitian ini di Perairan Tabukan Tengah Kabupaten Kepulauan Sangihe. Waktu pelaksanaan bulan Maret-Juni 2011. Pengumpulan data dengan cara partisipasi aktif dan pengamatan langsung pada proses operasi penangkapan ikan dari semua jenis alat tangkap yang digunakan oleh nelayan, wawancara dan pengisian daftar pertanyaan (kuisioner). Jumlah sampel yang diamati pada setiap jenis alat tangkap berkisar antara $30-50 \%$ dari jumlah alat tangkap. Data yang dikoreksi berupa jumlah dan jenis alat tangkap, daerah penangkapan, musim penangkapan, jenis ikan target, teknik dan proses operasi dan hasil jenis dan ukuran ikan tangkapan. Wawancara dilakukanterhadap nelayan tangkap, nelayan pemilik, sedangkan responden dikumpulkan secara pencuplikan yaitu dengan memastikan diperofebnya sejumlah sampel yang mewakili pópulàsi yang diteliti (Mangkusubroto dan Trisnadi 1985).

\section{HASIL DAN PEMBAHASAN}

Alat penangkap ikan yang digunakan oleh nelayan di perairan pantai Tabukan Tengah sangat bexagam dan sebagian besar tergolong skala keeril dan cenderung tradisional. Adapun junfäh dan jenis alat tangkap ikan yang diamati atau diteliti adalah jaring insang dasar 4 jenis dengan sampel amatan sebanyak 7 unit, jaring insang permukaan 1 jenis dengan sampel amatan 2 unit, jaring insang lingkar 3 jenis dengan sampel amatan 3 unit, jaring kantong 1 unit, pancing tangan 3 jenis dengan sampel amatan 3 unit, pancing mata banyak 2 jenis dengan sampel amatan 2 unit, pancing gurita 1 unit, perang- kap 4 jenis dengan sampel amatan sebanyak 4 unit, panah ikan 1 unit dan ladung penyu 1 unit.

Analisis data tangkapan setiap jenis alat dalam jangka panjang untuk melihat kecenderungan penurunan total tangkapan, perubahan komposisi jenis dan ukuran ikan tidak dapat dilakukan karena kurang tersedianya data yang memadai. Evaluasi dampak hanya dilakukan melalui pengamatan langsung dan inspeksi menyelam terhadap proses penangkapan ikan, untuk mengetahui kerusakan fisik bentik akibat alat tertentu, dengan mengukur tingkat atau lutasan kerusakan habitat, komposisi jentís dañ ukuran ikan.

Berdasarkan analisis proses operasional perikanan tangkap yang digunakan nelayan, maka evaluasi dampak metode penangkapan ikan terhadap lingkungan dapsumberdaya diringkaskan pada Tabel 1. Alat tangkap jaring insang dasar yang terdiri dar soma bawuluse, soma tataing, soma fanting-anting, soma gorango memberikan danpak yang paling besar pada habitat fisstk dasar perairan karena menggunakan pemberat batu yang sering tersangkut pada terumbu karang. Menghindari kerusakan terumbu karang, maka alat tangkap ini sebaiknya dioperasikan pada kedalaman minimal $40 \mathrm{~m}$. Jaring insang dasar juga berpotensi menyebabkan kelebihan tangkap dan mempengaruhi keragaman spesies terutama untuk jenis soma antinganting yang khusus ditujukan untuk menangkap sumberdaya lobster, jika dioperasikan secara terus menerus pada suatu daerah yang terbatas. Apabila alat tangkap ini hilang, maka secara intensif akan berperan sebagai ghost fishing, yaitu terus menangkap ikan secara efektif tanpa adanya kontrol dari pemiliknya.

Jaring insang hanyut khususnya soma sako tidak berdampak pada habitat perairan, kecuali jangkar yang dapat tersangkut karang. Alat ini berpotensi menyebabkan lebih tangkap rekrut jika menggunakan ukuran mata jaring lebih kecil dari 2 inci, atau ikut tertangkapnya jenis ikan muda lainnya. Ukuran ikan Cendro (Tylosurus crocodilus) yang tertangkap berkisar antara panjang 50-80 cm. Musbir et al. (2006) menyatakan bahwa ikan Cendro matang gonad pada ukuran di atas $75 \mathrm{~cm}$. Hasil tangkapan tersebut menunjukan bahwa masih berpeluang tertangkapnya ikan-ikan berusia muda yang belum memasuki usia pemijahan. Jaring insang hanyut lainnya yaitu soma bendera dan soma landara tidak memberikan dampak terhadap lingkungan karena dioperasikan menghanyut di dekat per- 
mukaan tanpa menyentuh dasar perairan. Kedua alat tangkap ini berpotensi terhadap tertangkapnya ikan-ikan muda jika menggunakan mata jaring ukuran kecil (<2inci).

Tabel 1. Dampak Alat Tangkap Terhadap Sumberdaya Ikan Dan Lingkungan.

\begin{tabular}{|c|c|c|}
\hline $\begin{array}{l}\text { Jenis Alat } \\
\text { Tangkap }\end{array}$ & $\begin{array}{c}\text { Sumberdaya } \\
\text { Ikan }\end{array}$ & Lingkungan \\
\hline $\begin{array}{l}\text { Jaring insang } \\
\text { dasar }\end{array}$ & $\begin{array}{l}\text { Tertangkap } \\
\text { ikan kecil }\end{array}$ & $\begin{array}{l}\text { Kerusakan } \\
\text { habitat dasar }\end{array}$ \\
\hline $\begin{array}{l}\text { Jaring insang } \\
\text { hanyut }\end{array}$ & $\begin{array}{l}\text { Tertangkap } \\
\text { ikan kecil }\end{array}$ & $\begin{array}{l}\text { Tidak } \\
\text { berdampak }\end{array}$ \\
\hline $\begin{array}{l}\text { Jaring insang } \\
\text { lingkar }\end{array}$ & $\begin{array}{l}\text { Tertangkap } \\
\text { ikan kecil }\end{array}$ & $\begin{array}{l}\text { Kerusakan } \\
\text { habitat dasar }\end{array}$ \\
\hline $\begin{array}{l}\text { Jaring } \\
\text { kantong }\end{array}$ & $\begin{array}{l}\text { Tertangkap } \\
\text { ikan kecil }\end{array}$ & $\begin{array}{l}\text { Kerusakan } \\
\text { habitat dasar }\end{array}$ \\
\hline Pukat cincin & $\begin{array}{l}\text { Tertangkap } \\
\text { ikan kecil }\end{array}$ & $\begin{array}{l}\text { Tidak } \\
\text { berdampak }\end{array}$ \\
\hline Pukat pantai & $\begin{array}{l}\text { Tertangkap } \\
\text { ikan kecil }\end{array}$ & $\begin{array}{l}\text { Kerusakan } \\
\text { habitat dasar }\end{array}$ \\
\hline $\begin{array}{l}\text { Jaring julung- } \\
\text { julung }\end{array}$ & $\begin{array}{l}\text { Ikan belum } \\
\text { memijah }\end{array}$ & $\begin{array}{l}\text { Tidak } \\
\text { berdampak }\end{array}$ \\
\hline Jala buang & $\begin{array}{l}\text { Tertangkap } \\
\text { ikan kecil }\end{array}$ & $\begin{array}{l}\text { Tidak } \\
\text { berdampak }\end{array}$ \\
\hline $\begin{array}{c}\text { Pancing } \\
\text { tangan }\end{array}$ & $\begin{array}{l}\text { Tertangkap } \\
\text { ikan kecil }\end{array}$ & $\begin{array}{l}\text { Kerusakan habitat } \\
\text { dasar }\end{array}$ \\
\hline $\begin{array}{l}\text { Pancing mata } \\
\text { banyak }\end{array}$ & $\begin{array}{l}\text { Tidak } \\
\text { berdampak }\end{array}$ & $\begin{array}{l}\text { Tidak } \\
\text { berdampak }\end{array}$ \\
\hline Pancing tonda & $\begin{array}{l}\text { Tidak } \\
\text { berdampak }\end{array}$ & $\begin{array}{l}\text { Tidak } \\
\text { berdampak }\end{array}$ \\
\hline Pancing gurita & $\begin{array}{l}\text { Tidak } \\
\text { berdampak }\end{array}$ & $\begin{array}{l}\text { Tidak } \\
\text { berdampak }\end{array}$ \\
\hline $\begin{array}{l}\text { Perangkap } \\
\text { ikan }\end{array}$ & $\begin{array}{l}\text { Tertangkap } \\
\text { ikan kecil }\end{array}$ & $\begin{array}{l}\text { Kerusakan } \\
\text { habitat dasar }\end{array}$ \\
\hline $\begin{array}{l}\text { Senapan } \\
\text { ikan }\end{array}$ & Selektif & $\begin{array}{l}\text { Kerusakan } \\
\text { habitat dasar }\end{array}$ \\
\hline Ladung penyu & $\begin{array}{l}\text { Spesies } \\
\quad \text { dilindungi } \\
\end{array}$ & $\begin{array}{c}\text { Tidak } \\
\text { berdampak }\end{array}$ \\
\hline
\end{tabular}

Jaring insang lingkarsoma pempelang yang ditujukan untuk menangkap ikan JulungJulung (Hemirhampus robustus) tidak memberikan dampak negatif terhadap lingkungan karena dioperasikan di laut dalam dan juga terhadap sumberdaya karen tidak dioperasikan secara intensif. Namun demikian jaring insang lingkar soma pako menyebabkan kerusakan habitat di terumbu Karang dan padang lamun, karena terinjak-injak oleh nelayan ketika mengejutkan ikan. Dampak terhadap sumberdaya terjadi karena ikut tertangkapnya ikan-ikan kecil ketika dihalau ke arah jaring.

Pengoperasian jaring kantong soma kinsaghe menyebabkan kerusakan habitat dasar perairan terutama terumbu karang dan padang lamun, karena terinjak-injak oleh nelayan ketika menggiring ikan ke arah kantong. Penggunaan mata jaring berukuran kecil terutama pada bagian kantong menyebabkan tertangkapnya ikan-ikan muda dalam jumlah cukup besar.

Dampak pengoperasian pukat cincin (soma pajeko) terhadap lingkungan hampir tidak ada; dan terhadap sumberdaya relatif kecil jika sesuai dengan ikan target, tetapi dapat berdampak tertangkapnya ikan-ikan muda jika beroperasi di rumpon. Pukat pantai atau soma sasangkile dapat memberikan dampak negatif terhadap lingkungan jika dioperasikan di daerah padang lamun dan dampak terhadap sunberdaya ialah tertangkapnya berbagai spésies ikan muda karena ukuran mata jaring pada-bagian kantong sangat kecil $(0,75$ inci) Ikán hasil tangkapan yang umumnya didominasi oleh ikan-ikan pelagis kecil seperti Jkan Tembang (Sardinella fimbriata), Sardtn (Sardinella sp.), Kerapu (Ephinephelu sp.), Kuwe (Caranx sp.) yang berukuran panjang $\geqslant-12 \mathrm{~cm}$.

Jaring ikan jullung-julung atau soma giop roa ditujukán khŭsus menangkap ikan julung-julung akan memijah. Penambahan upaya dan jumlah unit penangkapan akan sangat berdampak pada keberlanjutan sumberdaya ikan tersebut dir alam.

- Jala buang atau dalombo tidak memberikan dampak negatif terhadap lingkungan karena dioperasikan di perairan berpasir atau berlumpur namun berdampak pada sumberdaya karena tertangkapnya ikan-ikan muda seiring dengan penggunaan ukuran mata jaring yang kecil.

Pengoperasian pancing dasar (bawae) yang ditujukan untuk ikan dasar berpotensi menimbulkan dampak kerusakan habitat apabila menggunakan jangkar, terutama di daerah terumbu karang yang mudah patah. Alat ini selektif tetapi memungkinkan merubah komposisi target spesies jika nelayan terkonsentrasi pada suatu daerah penangkapan ikan yang terbatas. Pengoperasian pancing pani, bawulu (minggunakan umpan hidup), noru, kakintu, bawalude dan bira-bira hampir tidak berdampak negatif terhadap lingkungan dan sumberdaya karena dilakukan di perairan dalam dan selektif terhadap hasil tangkapan. Pancing gurita (gara-gara boboca) memberikan dampak yang kecil terhadap lingkungan dan dampak terhadap sumberdaya gurita dapat terjadi pada tingkat eksploitasi yang tinggi karena permintaan pasar yang terus meningkat.

Alat tangkap bubu yang terdiri dari $p a-$ hato, somba dan tumpina berdampak negatif pada habitat perairan karena nelayan menimbun alat tangkap dengan batu karang atau patahan 
karang untuk menyamarkannya, kecuali bebihe yang dioperasikan menghanyut di atas dasar perairan. Semua jenis bubu ini berpotensi menangkap ikan-ikan muda. Perangkap ikan yang hilang juga akan berperan sebagai ghost fishing.

Panah ikan (jubi) umumnya sangat selektif terhadap jenis dan ukuran ikan yang akan ditangkap. Kelebihan tangkap mungkin dapat terjadi pada intensitas penangkapan yang tinggi pada wilayah yang terbatas. Kerusakan habitat terumbu karang terjadi disebabkan karena terinjak oleh nelayan jubi. Dapat juga terjadi bahwa ikan yang berukuran relatif besar akan meronta-ronta diantara celah karang ketika terkena panah. Jika ikan tersebut sulit dikeluarkan, maka nelayan akan membongkar karang tersebut.

Walaupun ladung penyu tidak memberikan dampak terhadap lingkungan, tetapi alat ini menangkap spesies yang dilindungi undangundang yaitu penyu hijau (Chelonia mydas).

Komposisi hasil tangkapan dan ukuran hasil tangkapan pada alat tangkap pukat cincin menunjukan $60 \%$ ikan layang yang tertangkap berukuran panjang cagak (fork length, FL) 20 $24,4 \mathrm{~cm}$. Ukuran tersebut menunjukan bahwa ikan yang ditangkap adalah ikan yang sudah pernah memijah sehingga secara biologis sudah mendukung keberlanjutan dari sumberdaya ikan layang. Arifin (2008) menyatakan bahwa ikan layang mencapai matang gonad pada FL lebih $18 \mathrm{~cm}$. FL ikan tembang yang matang gonad adalah 16,3 cm (betina) dan 15,5 cm (jantan), ikan kembung matang gonad memfliki FL 22$24 \mathrm{~cm}$ dan ikan tongkol 28-30 cm (Yusfiandayani 2004). Hal ini berkaitan dengan ukuran rata-rata hasil tangkapan dari pukat pantai untuk ikan tembang yang tertangkap masih belum memenuhi kelayakân tangkap dan jenis-jenis pancing untuk ikankernbung dan ikan tongkol. Ikan cakalang yang tertangkap dengan alat tangkap pancing kakintu dengan $\mathrm{FL} 42,3 \mathrm{~cm}$, dan pukat cincm dengan FL 40,0 cm adalah layak tangkap karena sudah pernah mengalami matang gonad atau perekrutan. Hal ini sejalan dengan penelitian sebelumnya dari Nugraha dan Rahmat (2008) yang menyatakan bahwa ikan cakalang pertama kali matang gonad pada FL $40,0-40,6 \mathrm{~cm}$.

Ikan kembung (Rastrelliger kanagurta) yang didapat dari hasil tangkapan pancing noru berukuran FL $32 \mathrm{~cm}$, hal ini sesuai dengan ukuran pertama kali matang gonad yang dikemukakan oleh Musbir (2006) mengemukakan bahwa ikan kembung pertama kali matang gonad pada ukuran FL 19,2-20,3 cm. Hal ini mendukung upaya kelestariannya.

Salah satu konsep pemecahan masalah terhadap dampak perikanan tangkap adalah mengembangkan perikanan rakyat terpadu antara local resources based, community based dan market based, yang harus dipandang dari sisi pembangunan wilayah pesisir dan pulau-pulau kecil. Model pengembangan yang perlu dirumuskan adalah bagaimana memilih teknologi penangkapan ikan yang bisa spesifik lokasi, sesuai jenis ikan target dan habitatnya, serta kombinasi dari alat tangkap yang ada déngan mempertimbangkan faktor biologi, ekonomi, sosial budaya masyarakat dan kelembagaan.

Berdasarkan data hasil survei terhadap aktivitas perikanan tangkap dil wilayah perairan ini ternyata sebagian besar masih menggunakan alat tangkap tradisional seperti pancing tangan, jaring insang, perangkap ikan, senapan ikan dan hanya alat tangkap pukat cincin yang dikategorikan semi modern. Hasil tangkapan dalam jumlah besar dihasilkan oleh alat tangkap pukat cincin dan pükat pantai.

- Hásil analisis faktor strategis internal berupa kekuatan dan kelemahan serta hasil analisis faktor strategis eksternal berupa peluang dan ancaman untuk dampak terhadap habitat dasar perairan menunjukan bahwa alat tangkap perangkap ikan, jaring insang lingkar dan pancing tangan yang dioperasikan di daerah rataan terumbu karang berpotensi memberikan dampak secara langsung terhadap terumbu karang sehingga perlu meminimalkan dampak dari penggunaan alat tangkap tersebut ke arah alat tangkap yang ramah lingkungan. Beberapa alat tangkap yang perlu direkomendasikan untuk dipertimbangkan sebagai alat tangkap alternatif yang tidak merusak terumbu karang antara lain pancing noru, pancing bawulu, pancing bawalude dan pancing pani. Rekomendasi yang perlu diberikan untuk meminimalkan dampak yang ditimbulkan terhadap sumberdaya adalah untuk perangkap ikan sebaiknya dikonsentrasikan pada satu lokasi saja.

Hasil analisis faktor strategis internal serta analisis faktor strategis eksternal terhadap kelangsungan sumberdaya ikan menunjukan bahwa alat tangkap pukat pantai, pukat cincin, jala buang, ladung penyu dapat berakibat buruk terhadap kelangsungan sumberdaya ikan. Untuk meminimalkan dampak terhadap sumberdaya ikan, sebaiknya penggunaan alat tangkap tertentu yang khusus menangkap satu jenis spesies 
perlu peninjauan kembali lewat peraturan yang jelas dan mengikat, sedangkan untuk alat tangkap jenis jaring sebaiknya ukuran mata jaring diperbesar untuk membiarkan sumberdaya ikan yang masih kecil untuk dapat meloloskan diri.

\section{KESIMPULAN}

Hampir semua alat tangkap ikan yang digunakan oleh nelayan di perairan pantai Tabukan Tengah Kabupaten Kepulauan Sangihe dapat menyebabkan kerusakan fisik habitat perairan $(46,4 \%)$ dan kerusakan sumberdaya perikanan $(71,4 \%)$. Alat tangkap yang paling besar dampaknya terhadap sumberdaya ikan dan lingkungan adalah bubu, jaring insang dasar dan jaring kantong. Perlu dilakukan pelarangan bagi alat tangkap ladung penyu atau pun jenis lain dengan target tangkapan spesies penyu yang dilindungi. Pengaturan jumlah upaya, alat tangkap dan daerah pengoperasian soma giop roa yang menangkap ikan julung-julung yang akan memijah.

\section{DAFTAR PUSTAKA}

Arifin F. 2008. Optimasi Perikanan Layang Di Kabupaten Selayar Propinsi Sumatera Selatan. Program Pasca Sarjana. IPB. Bogor. 71 hal

Reppie E, Budiman J. 2007. Rencana Strategi Penelitian PS-PSP (Lab. TPI) Fakultas Perikanan Dan Ilmu Kelautan Unsrat, Suatu Bahan Pemikiran. 5 hal.

Reppie E, Modaso V, Paransa I. 2010. Evaluasi Dampak Beberapa Alat Tangkap Terhadap Sumberdaya Perikanan dan Habitatnya di Desa Bahoi, Selat Bangka, Kabupaten Minahasa Utara.

Mangkusubroto K, Trisnadi CL. 1985. Analisis Keputusan Pendekatan Sistem dalam Manajemen Usaha dan Proyek. Ganeca Exact. Bandung. Hal 271.

Musbir. 2006. Pendugaan Ukuran Pertama Kali Matang Gonad Ikan Kembung Rastreliger /kanagurta Di Perairan Laut Flores. Sulawesi Selatan. J. Sains dan Teknologi, 6 (1): 19-26.

Nugraha B, Rahmat E. 2008. Status Perikanan Huhate (Pole and Line) di Bitung Sulawesi Utara. Jurnal Penelitian Perikanam fndonesia. 14 (3). hal 311-318.

Yusfiandayani R. 2004。Studi Tentang Mekanisme Berkumpulnya Ikan Pelagis Kecil di Sekitar Rumpon dan Pengembangan, Perikanan di Perairan Pasauran, Provinsi Banten. Disertasi. Sekolah Pascasarjana Institut Pertanian Bógor. 106 hal.

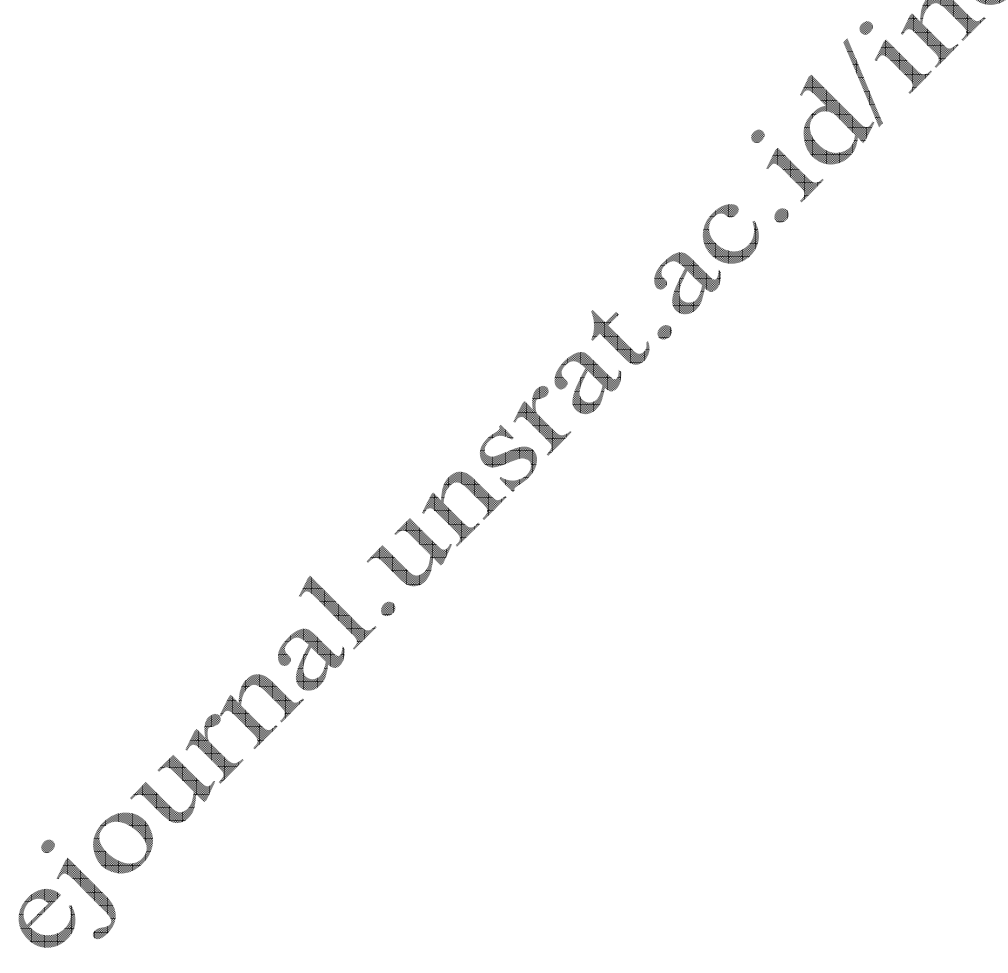

